\title{
Brazil's potential for generating electricity from biogas from stillage
}

\author{
Reginaldo Ferreira Santos ${ }^{1 *}$, Augustinho Borsoi ${ }^{1}$, Deonir Secco ${ }^{1}$, Samuel Nelson Melegari \\ de Souza ${ }^{1}$, Ricardo Nagamine Constanzi ${ }^{1}$ \\ ${ }^{1}$ State University of western Paraná, Cascavel, Brazil \\ *Corresponding author. Tel: +55 33213155, E-mail: rfsantos@unioeste.br
}

\begin{abstract}
The aim of this study was to evaluate potential of vinasse as an alternative source of electricity generation through the burning of biogas produced by anaerobic digestion process. The stillage residue is a process of producing ethanol, used as fertilizer on farming's, but with environmental problems of its application. This study was conducted on the basis of theoretical data to calculate the potential for methane generate and energy. Our purpose is to use an up flow anaerobic-UASB to accomplish the digestion of stillage and engines to burn the gas and electric power generation. The paper presents a case study of a distillery with a production of $580 \mathrm{~m}^{3}$ day $^{-1}$ ethanol. In Brazil in the harvest 2009/10 would have produced the stillage potential to produce 1.81 billion $\mathrm{m}^{3}$ of methane and $4.070 \mathrm{GWh}$ of energy. Whereas the case study of sugarcane in the interior of Parana, are produced 5,800 $\mathrm{m}^{3}$ day $^{-1}$ stillage, with the potential to generate $2.75 \mathrm{MWh}$ of electricity $\mathrm{month}^{-1}$, which results in a income of US\$218,586,32 a month. The use of vinasse as a source of energy has great potential energy for Brazil.
\end{abstract}

Keywords: Cane Sugar, Anaerobic Digestion, UASB, Renewable Energy.

\section{Introduction}

Sugar cane is as one of the most promising crops of the country to generate energy through biomass. To produce $1 \mathrm{~m}^{3}$ of alcohol are needed 13 tons of cane sugar, which should generate $10 \mathrm{~m}^{3}$ of slop, this figure varies from 10 to $15 \mathrm{~m}^{3}$. Due to nutrient content, stillage is used of fertigation, as far as not even there an alternative more practical and economical use of this waste, and in this case, there is an effective cost reduction with fertilization [1].

Despite the significant amount of fertilizer, this residue has a huge potential for generating energy by converting organic matter into methane, while minimizing any risk of accidents during handling of this waste, facilitating its application in agriculture due to increased $\mathrm{pH}$ neutralization of the effluent [1], [2].

The use of vinasse as fertilizer causes concern because of their high degree of impact when distributed in the environment, while there are technological mastery of the chain of sugar cane, today there is real need for studies to would define the best rate application in the extrinsic characteristics of soil and vinasse [2].

Due to the chemical oxygen demand (COD) is the a wastewater stillage with high pollution potential. The reason for this striking power is due to the high content of colloidal organic matter, which leads to oxidation of virtually all the available oxygen in the water. The use of stillage for biogas production is an alternative that may become viable economically and environmentally by three points: treatment of the waste, producing biogas for electricity generation and still has treated fertilizer of application in farming's [2].

With the increase of ethanol production in recent years, there was increased production of vinasse, increasing the environmental risks of its application in nature. Seeking an alternative for the treatment of stillage and also produce renewable energy, the objective this study was to evaluate the potential use of vinasse as an alternative biomass in the Brazilian energy as a source of generating electricity by burning biogas generated by anaerobic digestion process. 


\section{Methodology}

This paper is an exploratory literature research and a case study, based on published data in literature. The sources consulted for the preparation of this work were government agencies and the productive sector of sugar cane from Brazil, using historical data from the past 20 years, compared to growth of the ethanol market in Brazil during this period.

Data regarding the production of sugar cane and ethanol were obtained from the Union of Industries of Cane Sugar (UNICA) [3], the representative organization of the sugar and ethanol from Brazil. The paper presents the process of biogas production in an up flow anaerobic reactor (UASB reactor), demonstrating feasibility aspects of the project.

The feasibility of anaerobic treatment of vinasse in Brazil was confirmed with the use of UASB reactors (reactors and up flow anaerobic sludge blanket) under conditions mesophilic and thermophilic and reactor fluidized, both with suspended biomass [2]. The UASB reactor enables the movement of stillage through a region with high concentration of microorganisms. This reactor allows the separation of solid phases, liquid and gas, with the gas being driven to the top and solids and liquids directed.

Following suggestion from Rego and Hernandez [1], the biogas collected should be sent to a pressurized gas tank in which pressure is maintained at 1.15 bar for a diaphragm. For safety and to prevent leaks, any possible unused of gas will be automatically sent to burn. The treated effluent will be sent through channels to ponds or storage tanks for later be used as liquid biofertilizer.

Table 3 shows the parameters used in the work to convert the theoretical potential for electric energy production of vinasse into electrical energy by burning biogas produced by its anaerobic digestion in UASB.

Table 1. Parameters used for the elaboration of the potential for energy production

\begin{tabular}{|c|c|c|c|}
\hline Parameter & Indicator & Unit & Reference \\
\hline Vinasse production & 10 & $\mathrm{~m}^{3} \mathrm{~m}^{-3}$ of ethanol & [3] \\
\hline Ethanol production & 90 & $\mathrm{Lt}^{-1}$ cane & [3] \\
\hline COD typical of vinasse & 20 & $\mathrm{~kg} \mathrm{~m}^{-3}$ & {$[4]$} \\
\hline Concentration methane in biogas & 60 & \% Methane & [5] \\
\hline Typical production of methane & 0.35 & $\mathrm{Nm}^{3} \mathrm{~kg}^{-1}$ CODremoved & {$[6]$} \\
\hline Net calorific value of methane & 35.558 & $\mathrm{~kJ} \mathrm{Nm}^{-3}$ & {$[7]$} \\
\hline $\begin{array}{l}\text { Overall efficiency of motor- } \\
\text { generator }\end{array}$ & 26 & $\%$ to IBW & [8] \\
\hline Energy & 9.88 & $\mathrm{kWh} \mathrm{m}^{-3}$ methane & $\begin{array}{l}\text { Calculated from the } \\
\text { PCI methane }\end{array}$ \\
\hline $\begin{array}{l}\text { Amount received from sale of } \\
\text { energy }\end{array}$ & 79.41 & US\$ $\mathrm{MWh}^{-1}$ & {$[9]$} \\
\hline Dollar exchange rate (US\$ 1.00) & 1.70 & $\mathrm{R} \$$ & Commodities- BMF \\
\hline
\end{tabular}

$\mathrm{Nm}^{3}=$ normal $\mathrm{m}^{3}$ 
For the calculations were accounted directly the amount of methane produced, discounting the other gases present in the biogas, using the theoretical stoichiometric value of $0.35 \mathrm{~m}^{3} \mathrm{CH} 4$ $\mathrm{kgDQO}^{-1}$ removed [6].

Contributing to the analysis, presents a case study from a plant producing $580 \mathrm{~m}^{3}$ day $^{-1}$ of ethanol, located within the State of Parana. With data from ethanol production proceeded to the calculations of potential generation vinasse quantity and biogas produced, and how much electricity could be generated using internal combustion engines to gas burning. The production of vinasse this plant is $5,800 \mathrm{~m}^{3}$ day $^{-1}$, since for each $\mathrm{m}^{3}$ of ethanol is produced approximately $10 \mathrm{~m}^{3}$ of vinasse.

The selling price of electricity was calculated based on power purchase auctions conducted by ANEEL (National Electric Energy Agency), federal government agency that regulates power sector. The available data were processed in a spreadsheet, for construction generation of graphs and figures of the potential production described [9].

\section{Results}

Brazil is the world's largest producer of sugar cane, Brazilian mills in the harvest 2009/10 sued 604.514 million tons (Figure 1), with estimates for the harvest 2010/11 season to process 651.514 million tones [3].

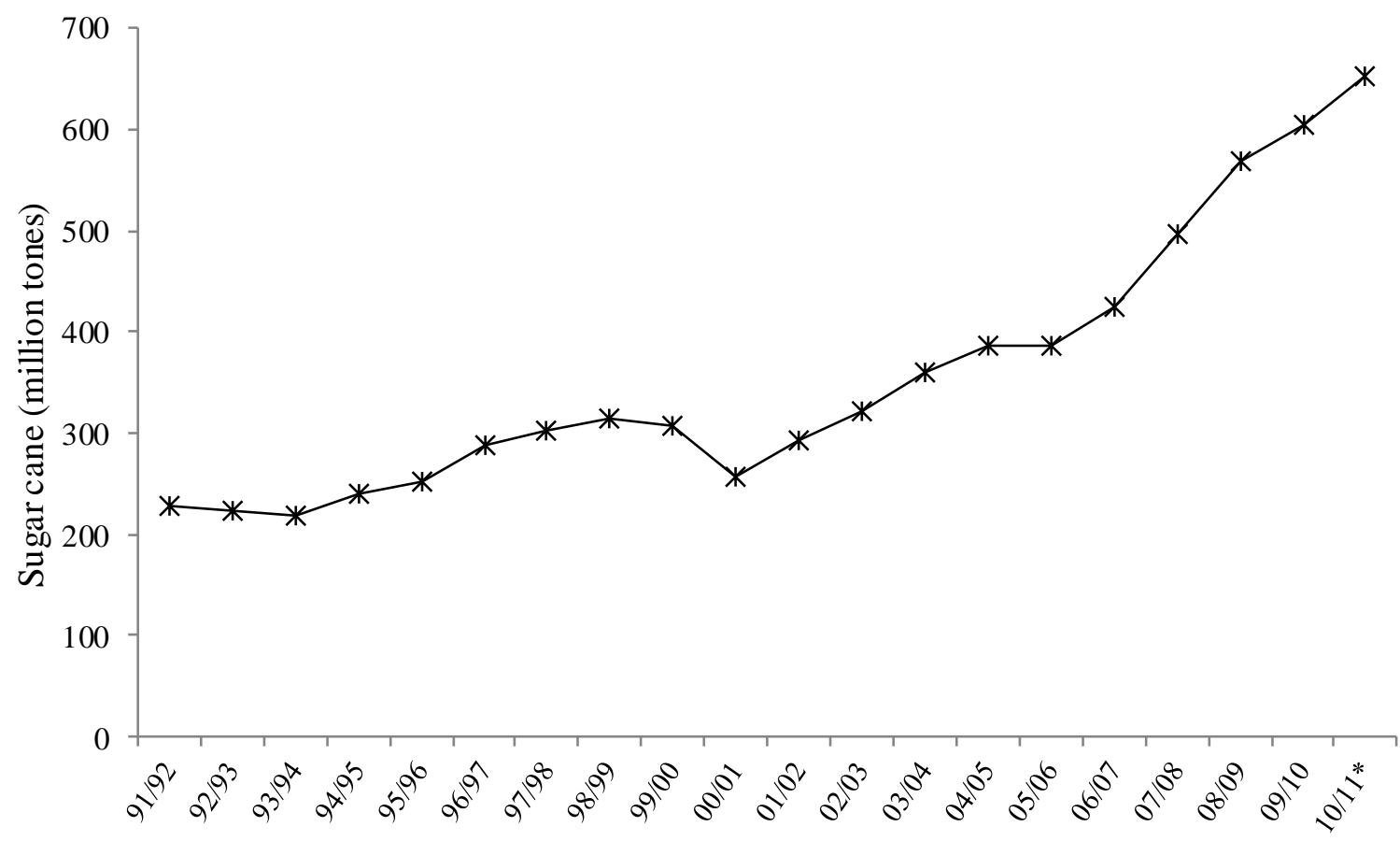

* Projection for the harvest 2010/11

Fig. 1. Sugar cane processed by mills in Brazil for sugar and ethanol.

Recent years have seen average growth of $14.6 \%$ per annum on the amount of sugar cane processed in Brazil, from 229.22 million tons in the harvest 1991/92 to 604.51 million tons in 2009/10, with growth forecast to 1 billion tons by 2015, up almost 50\% over the 2009/10 crop, increasing production of ethanol and sugar and generating more effluent. 


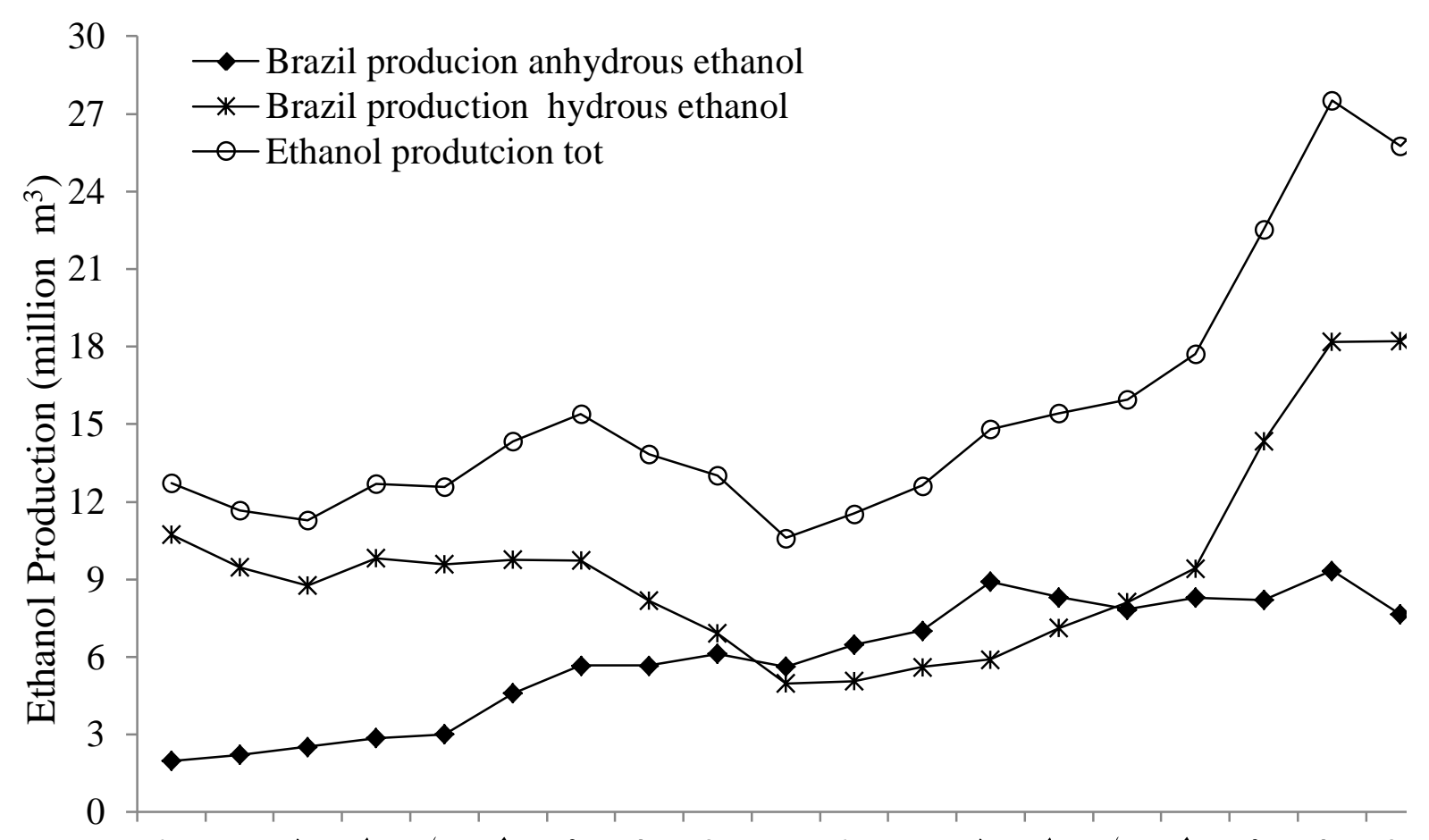

* Projection for the harvest 2010/11

Fig. 2. Comparative history of Brazilian ethanol anhydrous, hydrated and total production

Looking at Figure 2, it appears that, in the harvest 2009/10 ethanol production was 25.8 million $\mathrm{m}^{3}$, being $70.7 \%\left(18.2\right.$ million $\left.\mathrm{m}^{3}\right)$ with ethanol and $29.3 \%\left(7.6 \mathrm{~m}^{3}\right)$ of anhydrous ethanol. Recent years was seen huge increase in ethanol production, mainly hydrated for use as fuel in car engines that run on ethanol or flex fuel. Also according to the data the average productivity of ethanol was $90 \mathrm{~L} \mathrm{t}^{-1}$ of sugar cane, a little above the average that is $85 \mathrm{~L} \mathrm{t}^{-1}$ [3].

In Figure 3, can be observed the potential production historic of vinasse in Brazil from the production of ethanol, whereas to produce one liter of ethanol are produced on average 10 liters of vinasse.

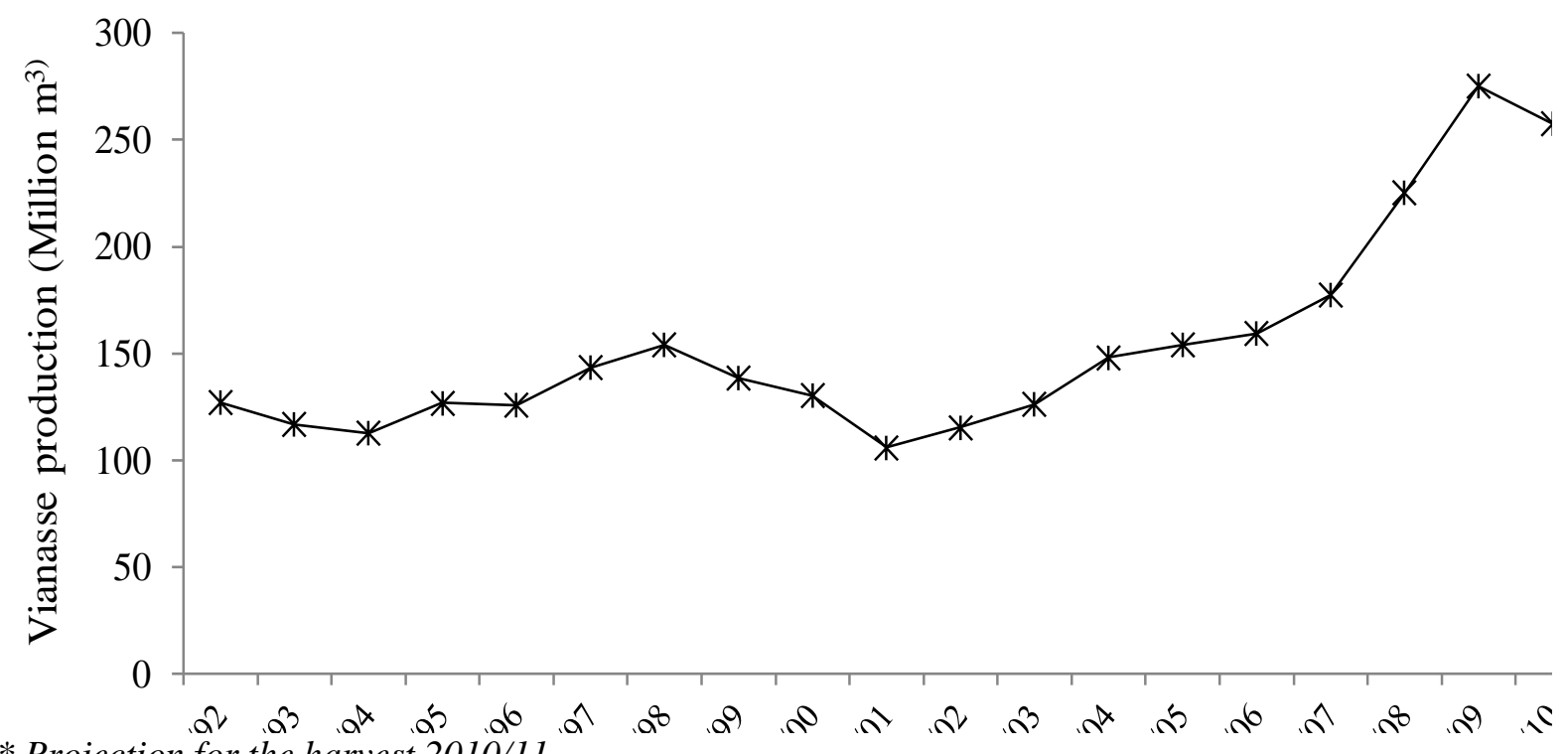

* Projection for the harvest 2010/11

Fig. 3. History of the Brazilian production of vinasse. 
According to literature data, it was found that for every liter of ethanol production, results in an average of 10 liters of vinasse. The potential for production of vinasse in Brazil in the harvest 2009/10 was 257.63 million of $\mathrm{m}^{3}$ (Figure 3), for the harvest 2010/11 the forecast is a production of 284.17 million $\mathrm{m}^{3}$, an increase of 26 million $\mathrm{m}^{3}$ compared the previous harvest.

Figure 4 presents the potential for methane production from vinasse in Brazil, considering that the whole stillage was treated by anaerobic digestion in UASB reactor type.

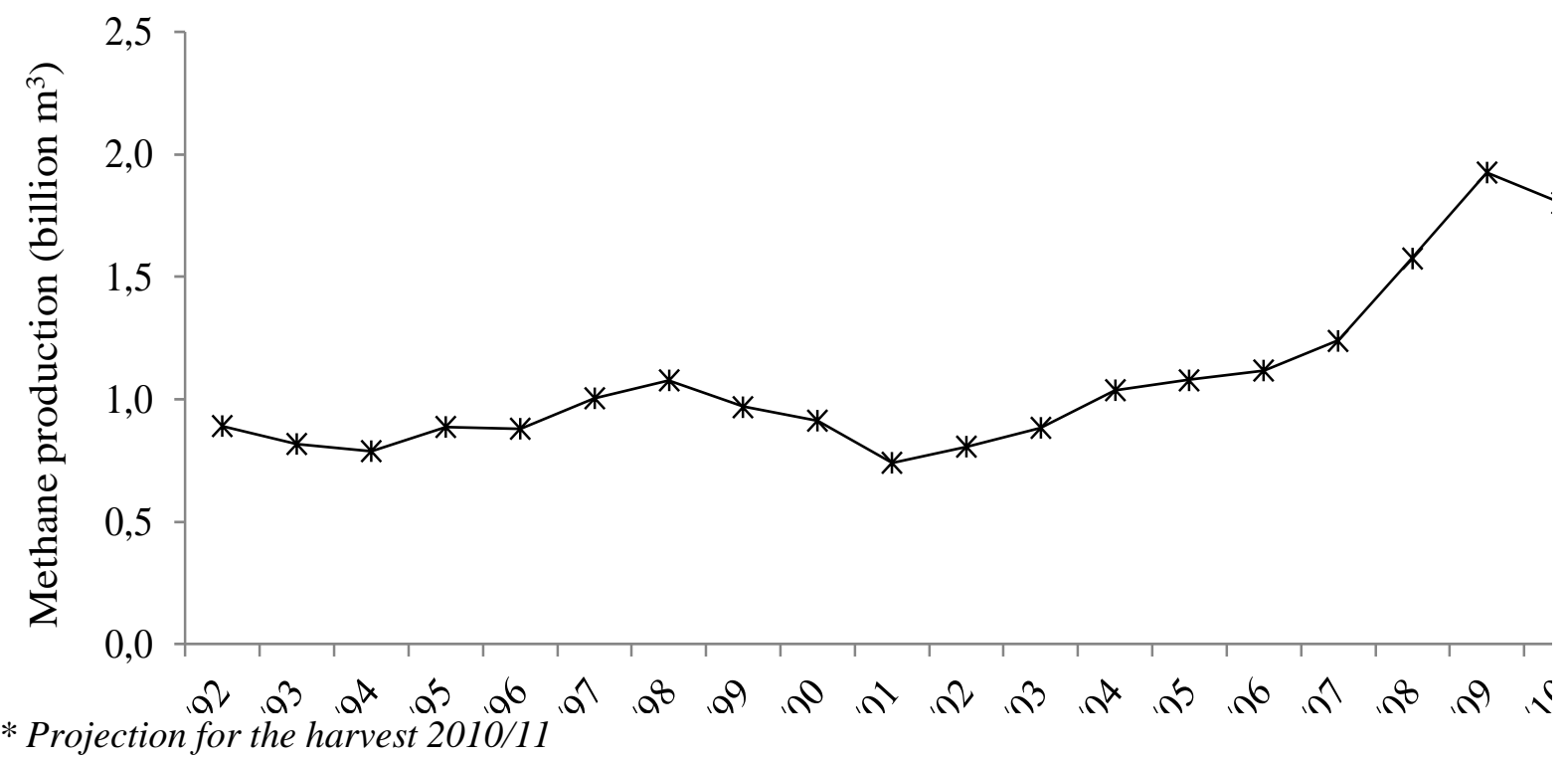

Fig. 4. History of the potential production of methane from the digestion of vinasse

The potential for methane production in the harvest 2009/10 would be 1.81 billion $\mathrm{m}^{3}$ (Figure 4) for $2010 / 11$ forecast of 1.98 billion $\mathrm{m}^{3}$, considering that the whole stillage produced by plants was transforming into methane gas, which could be burned in engines to generate mechanical energy or thermal energy, and transformed into electrical energy.

Figure 5 shows the historical potential of generating electricity from the burning of biogas from the digestion of vinasse in UASB reactors, using internal combustion engines.

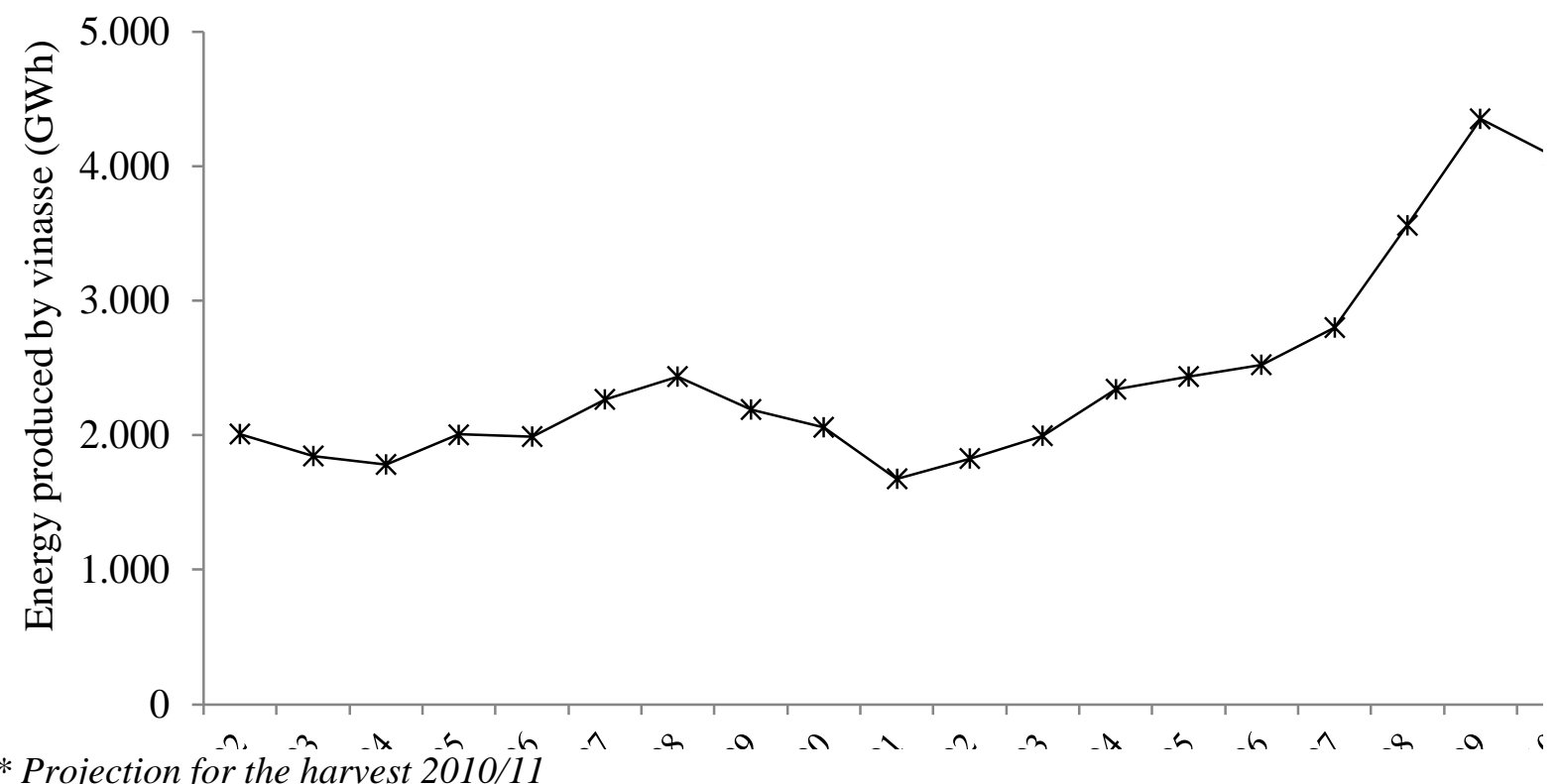

Fig. 5. History of the potential for electric energy production by vinasse. 
The historical potential for generating electric power from the stillage (Figure 5), if it was all treated in digesters and the biogas gotten burned for power generation. If added all the production of the last 20 years, we would have a potential to generate 50,700 GWh of electricity.

For a production of 605 million tons of processed cane sugar in Brazil in the harvest 2009/10, using the anaerobic digestion process, we obtain a potential to produce approximately 1.4 billion $\mathrm{m}^{3}$ of methane, would amount to 4.075 thousand GWh of electricity, equivalent to about $5 \%$ of the generation of the Itaipu plant, the world's largest hydroelectric dam, which generated during the year 2009 produced 91 thousand GWh, almost 20\% of Brazilian electricity, which totaled to 466.16 thousand GWh in 2009.

\subsection{Commercialization of energy produced}

In the 2009/10 cane crop, the potential value received by throughout the production of energy, sold at a price of US\$ 79.41 MWh (MWh price paid by system auctions conducted by ANEEL), generating revenues of US\$ 323.6 million for the plants, by the production of 4.075 GWh of electrical energy.

\subsection{Case study}

The following table (Table 2) presents a case study of a sugar and ethanol located in the State of Parana, Brazil. The facility has an area of approximately 6,000 ha of planted area, between owned and leased areas and a producing $580 \mathrm{~m}^{3}$ of alcohol/day.

Outcome of case study of an ethanol plant

\begin{tabular}{lcl}
\hline Parameter & Indicator & \multicolumn{1}{c}{ Unit } \\
\hline Vinasse production & 5,800 & $\mathrm{~m}^{3} \mathrm{day}^{-1}\left(241.67 \mathrm{Nm}^{3} \mathrm{~h}^{-1}\right)$ \\
Methane gas production & 40,600 & $\mathrm{Nm}^{3} \mathrm{~d}^{-1}\left(1691.6 \mathrm{Nm}^{3} \mathrm{~h}^{-1}\right)$ \\
Power generation & $91,752.28$ & $\mathrm{kWh} \mathrm{day}^{-1}\left(91.75 \mathrm{MWh} \mathrm{day}^{-1}\right)$ \\
Produced energy monthly & $2,752.57$ & $\mathrm{MWh} \mathrm{month}$ \\
Monthly price from the sale of energy & $218,586.32$ & $\mathrm{US} \mathrm{month}^{-1}$ \\
\hline
\end{tabular}

The plant produces $5,800 \mathrm{~m}^{3}$ daily stillage, which is used in fertigation of planting areas of the plant. Itself this stillage was used to produce methane gas ode through the process of anaerobic digestion in UASB reactor, would have a potential to generate $91.75 \mathrm{MWh} \mathrm{day}^{-1}$, or 2.75 thousand MWh month ${ }^{-1}$. If this energy was marketed at prices current (US\$ 79.41 MWh) would generate revenues of US\$218,586.32 month for the plant, beyond diversify their revenues.

\section{Discussion and Conclusions}

For this study, was used a potential of producing 10 liters of vinasse per liter of ethanol, the literature speak that to each liter of ethanol are produced 10 to 15 liters of vinasse [11], other authors argue that in producing 1 liter of ethanol produces a quantity minim than 10 liters of vinasse [12].

With respect to COD from stillage, the literature says that every $\mathrm{m}^{3}$ of ethanol generates 200 to $500 \mathrm{~kg}$ of COD, in study was considered a minimum quantity of $200 \mathrm{kgCOD} \mathrm{m}^{-3}$ ethanol. From the amount of COD was estimated production potential of methane [13], [2]. 
The calorific value of biogas is variable and is in the range from 22.500 to $25.000 \mathrm{~kJ} \mathrm{~m}^{-3}$, admitting the methane with about $35,580 \mathrm{~kJ} \mathrm{~m}^{-3}$. This means a recovery from 6.25 to $10 \mathrm{kWh}$ $\mathrm{m}^{-3}$ [14]. Due to the high concentration of methane in the biogas and consequently your potentially flammable, the main applications are in generating heat, cold and power [11].

Studies show that for the harvest 2004/05, the potential for producing electricity using the biogas produced by digestion of vinasse in motor-generators, internal combustion was 9.292 $\mathrm{TJ}$ year $^{-1}$ (2.6 $\mathrm{TWh}$ year $^{-1}$ ), representing $0.75 \%$ of national consumption of electricity in the year 2003 [5], data similar to those found in this work, where for the harvest 04/05 identified a potential to generate $2,43 \mathrm{GWh}$.

Lamo has built a prototype plant for the demonstration, consisting of a production unit (reactor of $120 \mathrm{~m}^{3}$ ), purification, compression and use of biogas. This plant produced gas fuel at levels up to $0.35 \mathrm{~m}^{3} \mathrm{CH} 4 \mathrm{kgCOD}^{-1}$ removed [15], agreeing with data of Cabello [16], that working with Ralf (fluidized bed reactor) also reached this relation.

Granato and Silva [2] performed a case study in a distillery with capacity to produce $600 \mathrm{~m}^{3}$ day $^{-1}$ of ethanol, as a result of digestion of stillage generated, they obtained a production of $75,600 \mathrm{Nm}^{3}$ biogas day ${ }^{-1}$. Considering a gas turbine efficiency of 35\%, production would be $6,540 \mathrm{kWh}$ of electrical energy alternative.

The stillage represents an important potential for renewable energy generation in Brazil, being a residue of ethanol production, which can generate energy and still be used as an important source of fertilizer for crops, in addition, your treatment will reduce environmental risks their application in nature.

\section{Acknowledgements}

The authors acknowledge Fundação Araucária, Coordenadoria de Aperfeiçoamento Profissional (CAPES) and Conselho de Desenvolvimento Tecnológico (CNPQ) for support in expenditure for registration and participation in the Congress.

\section{References}

[1]. E. E. Rego, F. Del M. Hernandez, Eletricidade por digestão anaeróbia da vinhaça de canade-açúcar: contornos técnicos, econômicos e ambientais de uma opção. In: Encontro De Energia No Meio Rural, 6., 2006. Anais... Campinas, Unicamp, 2006.

[2]. E. F. Granato, C. L. Silva, Geração de energia elétrica a partir do resíduo vinhaça. In: Encontro de Energia no Meio Rural, 4., 2002, Campinas. Anais eletrônicos... Campinas: Unicamp, 2002. Disponível em: <http://www.feagri.unicamp.br/energia/agre2002/pdf/0027.pdf> Acesso em: 22 ago. 2010.

[3]. União Da Indústria De Cana-De-Açúcar - UNICA, Dados e Cotações. 2010. Disponível em: <http://www.unica.com.br/default.asp> Acesso em: 20 set. 2010.

[4]. W. J. Freire, L. A. B. Cortez, Vinhaça de cana-de-açúcar. Ed. Agropecuária, Guaíba. 2000. 203p.

[5]. H. M. Lamonica, Potencial de geração de excedentes de energia elétrica a partir da biodigestão da vinhaça, Campinas, 06 jun. 2006. Palestra proferida no AGRENER 2006. 
[6]. M. Perez, R. Rodriguez-Cano, L. I. Romero, D. Sales, Anaerobic thermophilic digestion of cutting oil wastewater: Effect of co-substrate. Biochemical Engineering Journal, v. 29, 250-257, Apr. 2006.

[7]. N. J. B. Castañón, Biogás, originado a partir dos rejeitos rurais. São Paulo, 2002.

[8]. C. Chevalier, F. Meunier, Environmental assessment of biogas co- or tri-generation units by life cycle analysis methodology. Applied Thermal Engineering, vol. 25, p. 3025-3041, dec. 2005.

[9]. Empresa De Pesquisa Energética - EPE, Os Leilões de Fontes Alternativas de Energia Elétrica de 2010. São Paulo: EPE, 2010.

[10]. L. A. B. Cortez, E. E. S. J. A. C. Lora, Biomassa no Brasil e no mundo. In: L. A. B. Cortez, E. E. S. Lora, E. O. Gomez (org), "Biomassa para energia”. Campinas: Editora UNICAMP, 2008.

[11]. T. Szmrecsányi, Tecnologia e degradação ambiental: o caso da agroindústria canavieira no Estado de São Paulo. Revista Informações Econômicas, São Paulo, Vol. 24, n.10, out. 1994.

[12]. M. T. Ludovice, Estudo do efeito poluente da vinhaça infiltrada em canal condutor de terra sobre o lençol freático. Campinas, FEC-UNICAMP. Dissertação de Mestrado, 1996.

[13]. V. Hanndel, Valorização de subprodutos gerados nas destilarias de etanol. São Paulo: 2003.

[14]. E. P. Jordão, C. A. Pessoa, Tratamento de esgotos domésticos. 3. ed. Rio de Janeiro: ABES - Associação Brasileira de Engenharia Sanitária e Ambiental, 1995. 720 p.

[15]. P. de Lamo, Sistema produtor de Gás Metano Através de Tratamento de Efluentes Industriais - METHAX/BIOPAQ - CODISTIL - Piracicaba, 1991.

[16]. P. E. Cabello, F. P. Terán, F. J. C. Scognamiglio, Tratamento de vinhaça em reator anaeróbio de leito Fluidizado. Engenharia Ambiental, v. 6, n. 1, p. 321-338, jan./abr. 2009. 